\title{
CLINICAL AND LABORATORY PARAMETERS IN THE DIFFERENTIAL DIAGNOSIS OF PLEURAL EFFUSION SECONDARY TO TUBERCULOSIS OR CANCER
}

Leila Antonangelo1, Francisco Suso $\operatorname{Vargas}^{2}$, Marcia Seiscento², Sidney

Bombarda $^{2}$, Lisete Teixera ${ }^{2}$, Roberta Karla Barbosa de Sales ${ }^{2}$

\begin{abstract}
Antonangelo L, Vargas FS, Seiscento M, Bombarda S, Teixeira L, Sales RKB. Clinical and Laboratory Parameters in the Differential Diagnosis of Pleural Effusion Secondary to Tuberculosis or Cancer. Clinics. 2007;62(5):585-90.
\end{abstract}

PURPOSE: To evaluate the clinical and laboratory characteristics of pleural effusions secondary to tuberculosis (TB) or cancer (CA).

METHODS: A total of 326 patients with pleural effusion due to TB $(n=182)$ or CA $(n=144)$ were studied. The following parameters were analyzed: patient gender, age and pleural effusion characteristics (size, location, macroscopic fluid aspect, protein concentration, lactate dehydrogenase (DHL) and adenosine deaminase activity (ADA) and nucleated cell counts).

RESULTS: Young male patients predominated in the tuberculosis group. The effusions were generally moderate in size and unilateral in both groups. Yellow-citrine fluid with higher protein $(\mathrm{p}<0.001)$ levels predominated in effusions from the tuberculosis group $(5.3 \pm 0.8 \mathrm{~g} / \mathrm{dL})$ when compared to the CA group $(4.2 \pm 1.0 \mathrm{~g} / \mathrm{dL})$, whereas DHL levels were more elevated in CA $(1,177 \pm$ $675 \times 1,030 \pm 788 \mathrm{IU} ; \mathrm{p}=0.003)$ than in TB. As expected, ADA activity was higher in the TB group $(107.6 \pm 44.2 \times 30.6 \pm 57.5$ $\mathrm{U} / \mathrm{L} ; \mathrm{p}<0.001)$. Both types of effusions presented with high nucleated cell counts, which were more pronounced in the malignant group $(\mathrm{p}<0.001)$. TB effusion was characterized by a larger percentage of leukocytes and lymphocytes $(\mathrm{p}<0.001)$ and a smaller number of mesothelial cells $(\mathrm{p}=0.005)$. Lymphocytes and macrophages were the predominant nucleated cell in neoplastic effusions. CONCLUSION: Our results demonstrate that in lymphocytic pleural exudate obtained from patients with clinical and radiological evidence of tuberculosis, protein and ADA were the parameters that better characterize these effusions. In the same way, when the clinical suspicion is malignancy, serous-hemorrhagic lymphocytic fluid should be submitted to oncotic cytology once this easy and inexpensive exam reaches a high diagnostic performance $(\cong 80 \%)$. In this context, we suggest thoracocentesis with fluid biochemical and cytological examination as the first diagnostic approach for these patients.

KEY-WORDS: Pleural effusion. Neoplasm. Tuberculosis. Adenosine deaminase. Exudates.

\section{INTRODUCTION}

The first step in the etiological investigation of a pleural effusion is to determine whether the effusion is a transudate or an exudate. Transudates reflect the presence of systemic disease with repercussions on the mechanisms of

\footnotetext{
${ }^{1}$ Service of Cytology of Division of the Central Laboratory- Hospital das Clínicas - University of São Paulo Medical School, São Paulo, Brazil.

${ }^{2}$ Pneumology, Hospital das Clínicas Heart Institute-Incor University of São Paulo Medical School, São Paulo, Brazil.

Email: lantonangelo@hcnet.usp.br

Received for publication on June 20, 2007

Accepted for publication on July 07, 2007
}

pleural fluid production and resorption'. In contrast, exudates reflect the presence of primary pleural disease and require etiological investigation ${ }^{1}$. However, considering worldwide epidemiological aspects, most cases of pleural effusion in Brazil result as a consequence of tuberculosis or cancer ${ }^{2.3}$. In this respect, although differential diagnosis must be a priority, it is often difficult due to the similar biochemical profiles and the predominance of lymphocytes in both conditions.

The gold standard for diagnosis of pleural tuberculosis is the identification of Mycobacterium tuberculosis in pleural fluid or tissue ${ }^{4}$. However, in clinical practice this identification is problematic because of the low identification 
rate of the bacillus (less than $30 \%$ in pleural fluid and approximately $50 \%$ in the pleura) and the slow growth of mycobacterium in culture (about 60 days) ${ }^{4}$. Therefore, in regions with a high prevalence of tuberculosis, pleural biopsy demonstrating a granulomatous inflammatory process is used for diagnosis since other granulomatous diseases such as sarcoidosis, mycosis and rheumatoid arthritis account for less than $10 \%$ of granulomatous findings in the pleura 5 .

On the other hand, the diagnosis of neoplastic pleural effusion is made based on the presence of malignant cells in the pleural fluid or tissue. The positivity rate of the cytological exam ranges from 40 to $87 \%$, higher than that obtained with a needle biopsy which ranges from 35 to $65 \%{ }^{1,6}$.

In this context, the objective of the present study was to describe the characteristics and laboratory performance of pleural fluid biochemical and cytological parameters from patients with tuberculosis or cancer.

\section{METHODS}

A total of 326 consecutive patients from the Pleural Outpatient Clinic with a diagnosis of pleural effusion due to tuberculosis $(n=182)$ or cancer $(n=144)$ were included. The criteria for establishment of the diagnosis of tuberculosis were: a) pleural biopsy demonstrating a granulomatous process, b) detection of $M$. tuberculosis in pleural fluid or tissue, and c) a compatible clinical history and radiologic exams, in patients with a lymphocytic exudate and adenosine deaminase (ADA) levels higher than $40 \mathrm{U} / \mathrm{L}$ as well as favorable clinical evolution after specific treatment. The diagnosis of cancer was based on the finding of neoplastic cells in pleural fluid or tissue obtained by needle biopsy. In inconclusive cases, diagnosis was established by thoracoscopy-guided biopsy, transbronchial biopsy or surgery.

The following variables were analyzed: gender, age and characteristics of the pleural effusion including size (evaluated by chest X-ray - postero-anterior and lateral views) which was classified according to involvement of hemithorax as: discrete $(<25 \%)$; moderate $(25$ to $75 \%$ ) or intense $(>75 \%)$. Location (uni- or bilateral) and macroscopic aspects of the pleural fluid (yellow-citrine, serohemorrhagic or chylous) were also evaluated. Total protein concentration (colorimetric biuret reaction, Cobas Integra 700) and lactate dehydrogenase (LDH) levels (kinetic ultraviolet method, Cobas Integra 700) were assayed in pleural fluid samples collected without the addition of anticoagulant. Samples collected with EDTA were used for oncotic cytology and cell count and for the quantification of ADA (colorimetric method of Giusti et al. ${ }^{7}$ ).

The study was approved by the local Ethics Committee and all patients signed a free informed consent form.

Statistical Analysis. The Mann-Whitney test and Z test were used for comparison between groups, with differences being considered significant when $\mathrm{p}<0.05$. Statistical analysis was performed using the SigmaStat program (V2.03; Jandel Scientific, San Rafael, CA).

\section{RESULTS}

The demographic data of the patients and the characteristics of the pleural effusions are shown in table $1 . \mathrm{Pa}$ tients with tuberculosis were significantly $(\mathrm{p}<0.001)$ younger $(36.7 \pm 13.6$ years $)$ than those with cancer $(58.5$ \pm 14.5 years $)$. Among patients with tuberculosis, there was a predominance $(\mathrm{p}<0.001)$ of males $(132 / 182 ; 72.5 \%)$ over females $(50 / 182 ; 27.5 \%)$, while the opposite was observed in the cancer group (females: 95/144, 66\% versus males: 49/144, 34\%; $\mathrm{p}<0.001)$. This finding reflects the characteristics of our outpatient clinic, where mainly breast cancer patients are seen.

Table 1 - Demographic data and characteristics of the pleural effusions.

\begin{tabular}{|c|c|c|c|}
\hline & Tuberculosis & Cancer & $\mathrm{p}$ \\
\hline $\mathrm{N}$ & 182 & 144 & NS \\
\hline Age (years) & $36.7 \pm 13.6$ & $58.5 \pm 14.5$ & $<0.001$ \\
\hline Gender $(\mathrm{M} / \mathrm{F})$ & $\begin{array}{c}132 / 50 \\
(72.5 / 27.5 \%)\end{array}$ & $\begin{array}{c}49 / 95 \\
(34 / 66 \%)\end{array}$ & $<0.001$ \\
\hline \multicolumn{4}{|c|}{ Size (\% of the hemithorax) } \\
\hline$<25$ & $32(17.6 \%)$ & $1(0.7 \%)$ & $<0.001$ \\
\hline $25-75$ & $142(78.0 \%)$ & $103(71.5 \%)$ & 0.187 \\
\hline$>75$ & $8(4.4 \%)$ & $40(27.8 \%)$ & $<0.001$ \\
\hline \multicolumn{4}{|l|}{ Location } \\
\hline Unilateral & $174(95.6 \%)$ & $133(92.4 \%)$ & 0.381 \\
\hline Bilateral & $8(4.4 \%)$ & $11(7.6 \%)$ & 0.342 \\
\hline \multicolumn{4}{|l|}{ Aspect } \\
\hline Yellow-citrine & $161(88.5 \%)$ & $69(47.9 \%)$ & $<0.001$ \\
\hline Serohemorrhagic & $21(11.5 \%)$ & $73(50.7 \%)$ & $<0.001$ \\
\hline Chylous & $0(0 \%)$ & $2(1.4 \%)$ & \\
\hline
\end{tabular}

With respect to fluid volume, we observed a predominance of moderate effusion in both groups (tuberculosis: 142/182; 78\%, and cancer: $103 / 144 ; 71.5 \%$ ), with no significant difference between them $(\mathrm{p}=0.187)$. Although most effusions were moderate, the lowest volumes $(<25 \%)$ were observed in the tuberculosis group $(32 / 182 ; 17.6 \%)$, whereas more voluminous effusions $(>75 \%)$ were most frequent in the cancer group $(40 / 144 ; 27.8 \%)$. Unilateral ef- 
fusions predominated in both tuberculosis $(174 / 182 ; 95.6 \%)$ and cancer (133/144; 92.4\%) groups.

Macroscopically, most pleural effusions presented a yellow-citrine aspect $(230 / 326 ; 70.5 \%)$, demonstrating a significant difference $(\mathrm{p}<0.001)$ between the tuberculosis $(161 / 182 ; 88.5 \%)$ and cancer $(69 / 144 ; 47.9 \%)$ groups. Although half of these effusions were yellow-citrine, serohemorrhagic effusions predominated $(\mathrm{p}<0.001)$ in the cancer group $(73 / 144 ; 50.7 \%)$ when compared to the tuberculosis group $(21 / 182 ; 11.5 \%)$.

Table 2 shows the biochemical and cytological characteristics of the pleural fluids. Protein concentrations were significantly higher $(\mathrm{p}<0.001)$ in the tuberculosis group $(5.3 \pm 0.8 \mathrm{~g} / \mathrm{dL})$ compared to the cancer group $(4.2 \pm 1.0$ $\mathrm{g} / \mathrm{dL})$. In contrast, LDH levels were higher $(\mathrm{p}=0.003)$ in the cancer group $(1,177 \pm 675 \mathrm{IU})$ than in the tuberculosis $(1,030 \pm 788 \mathrm{IU})$ group. Finally, as expected, ADA levels were significantly higher in the tuberculosis group (107.6 $\pm 44.2 \mathrm{U} / \mathrm{L}$ versus $30.6 \pm 57.5 \mathrm{U} / \mathrm{L} ; \mathrm{p}<0.001$ ).

Although the pleural effusions were characterized by high cellularity, neoplastic effusions were more richly cellular than tuberculous effusions $(3,058 \pm 1,807$ versus 2,860 $\pm 2,194$ cells $\left./ \mathrm{mm}^{3} ; \mathrm{p}<0.001\right)$. Analysis of the proportion of nucleated cells revealed a significantly lower percentage of mesothelial cells in the tuberculosis group $(1.3 \pm$ $2.2 \%$ versus $6.1 \pm 1.6 \% ; \mathrm{p}=0.005)$, whereas the percentage of macrophages was significantly higher $(\mathrm{p}<0.001)$ in the cancer group $(33.2 \pm 23.4 \%$ versus $10.5 \pm 10.2 \%)$. A higher proportion of leukocytes $(\mathrm{p}<0.001)$ was observed in the tuberculosis group $(87.8 \pm 11.7 \%)$ when compared to the cancer group $(57.5 \pm 26.8 \%)$. Although both effusions were lymphocytic, the number of lymphocytes was significantly higher $(\mathrm{p}<0.001)$ in the tuberculosis $(88.9 \pm$ $19.7 \%)$ compared to the cancer group $(81.7 \pm 22.4 \%)$.

In cancer effusions, oncotic cytology was positive in $70 \%$ (101/144) of cases and highly suggestive in $19.2 \%$ (28/ 144), permitting suspicion or confirmation of diagnosis in approximately $90 \%$ of the patients. A second pleural approach (thoracocentesis) confirmed the diagnosis of can- cer in four suspected cases and in additional two whose cytology was negative. In the remaining 24 patients, cytology was inconclusive. The diagnosis of cancer was confirmed by immunophenotyping of pleural fluid in four cases (lymphoma), by closed pleural biopsy in 13 (carcinoma), and by thoracoscopy-guided pleural biopsy in seven (carcinoma).

Closed pleural biopsy was conclusive in 68/78 (87.1\%) and 21/37 (56\%) of tuberculosis and cancer patients, respectively. A second pleural biopsy increased the cancer rate to $23 / 37(62.1 \%)$.

\section{DISCUSSION}

A systematic approach to the classification of pleural effusion permits the diagnosis of a large number of pleural diseases, especially when considering the high incidence of tuberculosis and cancer in Brazil. Diagnostic exploration is based on the analysis of clinical variables (gender, age and symptoms), imaging characteristics (volume and location of fluid), and laboratory (biochemical and cytological) data.

A detailed clinical history of previous neoplasms or complaints related to consumptive states, as well as the presence of fever, night sweats, cough and contact with tuberculous patients are fundamental. Since thoracocentesis is the first approach proposed in cases of pleural effusion, analysis of the removed fluid is the easiest and fastest way of assessment ${ }^{8}$. Although the cause of pleural effusion remains indeterminate in about $20 \%$ of cases, cytological, biochemical and microbiological analysis of pleural fluid is fundamental for adequate screening, avoiding more expensive exams that would increase the morbidity and/or mortality of the patient 9 .

Tuberculosis is a ubiquitous disease with a high prevalence in Brazil ${ }^{3}$. This disease usually predominates among individuals younger than those affected by cancer, a fact confirmed in the present study in which only $4.2 \%$ of the cases of tuberculosis occurred in patients older than 35

Table 2 - Biochemical and cytological characteristics of the pleural fluids.

\begin{tabular}{lcccc}
\hline & & Tuberculosis & Cancer & $\mathrm{p}$ \\
\hline Protein & $(\mathrm{g} / \mathrm{dl})$ & $5.3 \pm 0.8$ & $4.2 \pm 1.0$ & $<0.001$ \\
DHL & $\mathrm{UI}$ & $1,030 \pm 788$ & $1,177 \pm 675$ & 0.003 \\
ADA & $(\mathrm{U} / \mathrm{L})$ & $107.6 \pm 44.2$ & $30.6 \pm 57.5$ & $<.001$ \\
& & & & \\
Nucleated cell count & $\left(\mathrm{mm}^{3}\right)$ & $2,860 \pm 2,194$ & $3,058 \pm 1,807$ & $6.1 \pm 1.6$ \\
Mesothelial cells & $(\%)$ & $1.3 \pm 2.2$ & $33.2 \pm 23.4$ & $<.001$ \\
Macrophages & $(\%)$ & $87.8 \pm 11.7$ & $57.5 \pm 26.8$ & $<.005$ \\
Leukocytes & $(\%)$ & $7.6 \pm 16.6$ & $13.3 \pm 19.2$ & $<0.001$ \\
Granulocytes & $(\%)$ & $88.9 \pm 19.7$ & $81.7 \pm 22.4$ & $<0.001$ \\
Lymphocytes & $(\%)$ & & $<0.001$ \\
\hline
\end{tabular}


(only one patient older than 60) years. However, in the state of São Paulo (1998 to 2000), notifications of pleural effusion due to tuberculosis indicate that $40 \%$ of cases occurred in male individuals older than 40 years. $^{2}$ Thus, although important, age should only be considered as a complementary variable in the diagnosis of tuberculosis.

With respect to gender, it is known that men are more predisposed to both tuberculosis ${ }^{10}$ and lung cancer, ${ }^{11,12}$ although the incidence of cancer has been increasing among women over the last few decades. The predominance of females among patients with cancer observed in the present study is in contrast to international epidemiological data. This bias is easily explained by the tertiary character of our hospital, which is a referral center for cancer with pleural involvement, particularly that secondary to breast cancer.

The pleural effusions were moderate in most patients with tuberculosis or cancer, with unilateral effusions predominating in more than $90 \%$ of cases. This finding agrees with literature showing that pleural effusions are preferentially unilateral and moderate. ${ }^{1,12}$ Despite this similarity, a higher incidence of voluminous collections is found in malignant pleural effusions, a fact also observed in the present study ${ }^{1}$.

After evaluation of demographic variables and chest images, the pleural space should be submitted to invasive investigation. The first step is thoracocentesis, i.e., thoracic puncture for pleural fluid collection, with the objective, in addition to the determination of macroscopic aspects, of material collection for adequate laboratory examination.

Yellow-citrine fluid (sometimes slightly turbid) predominates in tuberculosis while serohemorrhagic fluid predominates in cancer. Our results confirmed this observation $^{8,13}$ but also showed overlaps between the groups concerning the classification of pleural effusion based only on this variable.

As a rule, thoracocentesis should always be considered for collection of pleural fluid for diagnosis. Only in exceptional cases, when diagnosis has already been established or during an emergency (respiratory insufficiency), will it be performed when no laboratory infrastructure is available. Otherwise, thoracocentesis should include fluid collection and subsequent biochemical and cytological exams.

The first parameters analyzed (LDH and protein) should permit the differentiation between a transudate and an exudate (Light's criteria). ${ }^{14}$ Clinically, this discrimination is extremely valuable, since transudative effusions generally reflect systemic diseases and therefore do not require a complementary diagnostic approach. On the other hand, exudates indicate pleural involvement resulting from systemic disorders or primary pleural diseases. In these cases, diagnostic exploration should be complemented by other pleural fluid exams or histological evaluation of the pleura. ${ }^{1,8}$

Since our objective was to differentiate between tuberculosis and cancer, the first step was to recognize the presence of an exudate. All pleural effusions included in the study were exudates and, although not specific, protein levels were significantly higher in the tuberculosis group, in agreement with the findings of Liam et al. ${ }^{15}$ Since the protein concentration in pleural tuberculosis is frequently higher than $4.5 \mathrm{~g} / \mathrm{dL}$, Melo et al. ${ }^{16}$ proposed this value as a cutoff for diagnostic presumption. As confirmation of this proposal, this was the minimum protein level detected in the present study.

Lactic dehydrogenase, a nonspecific inflammatory marker ${ }^{8}{ }^{8}$ is in general discretely elevated in pleural tuberculosis. Neoplasms present higher levels, suggesting a greater extent of pleural disease or the presence of blood in the pleural cavity. ${ }^{17}$ Despite this difference and, as is the case for the macroscopic evaluation of effusion, these biochemical parameters do not permit differentiation between the two diseases because of overlapping values.

The next step is the quantification of ADA, an enzyme produced by macrophages and activated $\mathrm{T}$ lymphocytes, ${ }^{18}$ which is usually elevated in tuberculosis. In this situation, the activity of the enzyme is generally higher than $40 \mathrm{U} /$ L, although similar levels are observed in lymphocytic pleural effusions secondary to rheumatoid arthritis and certain lymphoproliferative diseases. Other lymphocytic exudates, such as those secondary to pulmonary edema or metastatic tumors, generally show levels below $40 \mathrm{U} / \mathrm{L} .{ }^{19-22}$ In the present study, using a cutoff value of $40 \mathrm{U} / \mathrm{L}$ as a presumptive diagnosis, all cases of tuberculosis were correctly classified. This cutoff value shows high efficiency in the classification of lymphocytic effusions (sensitivity: 87 to $100 \%$ and specificity: 81 to $97 \%$ ). ${ }^{19-25}$ Despite the high diagnostic sensitivity of ADA, its specificity is influenced by other clinical conditions and by the regional prevalence of tuberculosis. ${ }^{26,27}$

In the present study, 13 (9\%) patients with cancer presented an ADA activity higher than $40 \mathrm{U} / \mathrm{L}$. Five of these patients had lymphomas (diagnosed by immunophenotypying) and eight had solid tumors. Despite increased ADA levels, etiological diagnosis was established in seven of these cases by pleural fluid cytology. In one case, both cytology and pleural biopsy were negative. However, chest $\mathrm{X}$-ray demonstrated a pulmonary mass and the diagnosis of undifferentiated lung carcinoma was established by transbronchial biopsy. In the remaining five cases, a closed pleural biopsy $(n=3)$ or thoracoscopy-guided biopsy $(n=2)$ led to a definitive diagnosis. 
Considering the cytological profile of the pleural fluids in these two diseases, no cellular finding is characteristic, with exception to the presence of neoplastic cells in cancer effusions.

Oncotic cytology of the pleural fluid is considered to be the most sensitive method for the diagnosis of malignant pleural effusion. ${ }^{1,8}$ However, its performance varies according to the histological type and exfoliative capacity of the tumor, the techniques used to process the pleural samples, the number of slides analyzed per case and, finally, the cytologist expertise. These factors explain the variation in the efficacy of the exam (40 to 87\%) reported in the literature. ${ }^{28}$ In this study, the first fluid examination led to the diagnosis of cancer in $70.1 \%$ (101) of cases. In $19.4 \%$ (28), oncotic cytology was highly suspicious of malignancy and in $10.5 \%$ (15) it was negative. A second method performed in the 28 suspicious patients (thoracocentesis: 4; immunophenotyping: 4; closed pleural biopsy: 13 and VATS: 7) defined the diagnosis of neoplasia. In all patients (15) with negative cytology, the diagnosis of cancer was confirmed.

This study demonstrates that although the pleural effusion exudates secondary to tuberculosis or cancer were pre- dominantly lymphocitic, some clinical and laboratory aspects could aid in their differentiation. In general, tuberculosis occurred in younger persons, and effusions were unilateral and of a median size. The pleural fluid was frequently yellow (citrine or turbid) with high protein and ADA levels and with a low number of mesothelial cells. In contrast, patients with malignant effusions were generally older and, although the effusions were predominantly unilateral, the presence of a bilateral effusion was more associated with malignancy. In addition, the fluid was predominantly turbid or serohemorrhagic. The level of protein was lower than in tuberculosis, while ADA was normal and LDH was frequently higher. Cytological examination revealed a predominance of lymphocytes and macrophages. In patients with clinical and radiological evidence of tuberculosis presenting an exudative effusion rich in lymphocytes, protein and ADA levels are important to the etiological diagnosis. Similarly, when the clinical suspicion is malignancy, serous hemorrhagic limphocytic fluid should be submitted to oncotic cytology, once this easy and

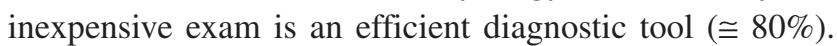
As a result, we suggest thoracocentesis with pleural fluid examination as the first diagnostic approach.

\section{RESUMO}

Antonangelo L, Vargas FS, Seiscento M, Bombarda S, Teixeira L, Sales RKB. Parâmetros clínicos e laboratoriais no diagnóstico diferencial de efusões pleurais secundárias à tuberculose ou ao cancer. Clinics.2007;62(5):585-90.

OBJETIVO: Avaliar as características clínicas e laboratoriais de derrames pleurais secundários à tuberculose ou câncer.

MÉTODOS: Um total de 326 pacientes com derrame pleural por tuberculose $(n=182)$ ou câncer $(n=144)$ foi avaliado. Os seguintes parâmetros foram analisados: sexo e idade dos pacientes e características do líquido pleural (tamanho, localização, aspecto macroscópico, concentração de proteínas, atividade da desidrogenase lática (DHL) e da adenosina deaminase (ADA) e contagem de células nucleadas).

RESULTADOS: A tuberculose pleural predominou nos pacientes mais jovens e do sexo masculino. Em ambos os grupos, os derrames pleurais foram de tamanho moderado e unilaterais. Derrames com aspecto amarelo-citrino com níveis mais elevados de proteínas predominaram na tuberculose $(5,3$ $\pm 0,8 \mathrm{~g} / \mathrm{dL})$, quando comparados aos neoplásicos (4,2 $\pm 1,0$ $\mathrm{g} / \mathrm{dL}$ ), enquanto que níveis mais elevados de DHL foram observados nos derrames neoplásicos (1.177 \pm 675 x 1.030 $\pm 788 \mathrm{UI} ; \mathrm{p}=0,003)$. Conforme esperado, a atividade da
ADA foi maior na tuberculose que no câncer $(107,6 \pm 44,2$ x 30,6 \pm 57,5 U/L; p < 0,001). Ambos os derrames apresentaram alta celularidade, embora mais pronunciada no grupo neoplásico $(\mathrm{p}<0,001)$. Os derrames de etiologia tuberculosa se caracterizaram por apresentar uma maior percentagem de leucócitos e de linfócitos ( $\mathrm{p}<0,001)$ e um pequeno número de células mesoteliais $(p=0,005)$. Linfócitos e macrófagos foram as células nucleadas que predominaram nos derrames pleurais malignos.

CONCLUSÃO: Nossos resultados demonstram que em exsudatos pleurais linfocíticos de pacientes com evidências clínicas e radiológicas de tuberculose, os níveis de proteína e de ADA foram os parâmetros que melhor caracterizaram esses derrames. Da mesma maneira, quando a suspeita clínica é câncer, um líquido serohemorrágico e linfocítico deve ser submetido à citologia oncótica, uma vez que este exame laboratorial de fácil realização e baixo custo apresenta alto desempenho diagnóstico ( $\cong 80 \%)$. Neste contexto, sugerimos que a toracocentese, com exames bioquímicos e citológicos do líquido pleural, seja a primeira abordagem diagnóstica do paciente.

UNITERMOS: Derrame pleural. Neoplasia. Tuberculose pleural. Adenosina deaminase. Exsudatos. 
1. Maskell NA, Butland RJA. BTS Guidelines for the Investigation of a Unilateral Pleural Effusion in Adults. Thorax 2003;58:8-17.

2. Centro de Vigilancia Epidemiológica Alexandre Vranjac. Secretaria da Saúde de São Paulo. URL:http//www.cve.saude.sp.gov.br/tuberculose (20/08/2006).

3. Instituto Nacional de Câncer - Ministério da Saúde. URL:http:// www.inca.gov.br (20/08/2006).

4. Gopi A, Madhavan SM, Sharma SK and Sahn SA. Diagnosis and Treatment of Tuberculous Pleural Effusion in 2006. Chest 2007;131:880-89.

5. Valdés L, Pose A, San José E and Martínez Vázquez JM.Tuberculous Pleural Effusions.EurJ Intern Med 2003;14:77-88.

6. Di Bonito I, Falconieri G, Colautti I, Bonifacio D and Dudine S. The Positive Pleural Effusions. A Retrospective Study of Cytopathologic Diagnosis with Autopsy Confirmation. Acta Cytol 1992;36:329-32.

7. Giust G. Adenosine Deaminase In: Bergmeyer HU. Methods of Enzymatic Analysis. New York Academic Press 1974;1092-99.

8. Light RW. Clinical Manifestations and Useful Tests. In: Pleural Diseases. $4^{\text {th }}$ ed, Philadelphia, Lippincott-Williams \& Wilkins, 2001. p. 42-86.

9. Villena V, López Encuentraz A, Echave -Sustaeta J, Alvarez Martinez C, Martin Escribano P. Prospective study of 1,000 consecutive patients with pleural effusion. Etiology the effusion and characteristics of the patients. Arch. Bronconeumol. 2002;38:21-6.

10. World Health Organization URL:www.who.int/gtb/policyrd/ Gender\&tb.htm (20/08/2006)

11. Parkin DM. Bray F, Ferlay J and Pisani P. Global Cancer Statistics, 2002. CA Cancer J Clin 2005;55:74-108.

12. Antunes G, Neville E, Duffy J, Ali N. BTS Guidelines for the Management of Malignant Pleural Effusions. Thorax 2003;58:29-38.

13. Porcel-Perez JM, Vives Soto M, Esquerda Serrano A, Jover Saenz A. Cutoff Values of Biochemical Tests on Pleural Fluid: Their Usefulness in Differential Diagnosis of 1040 Patients with Pleural Effusion. Ann Med Intern 2004;21:113-17.

14. Light RW, MacGregor MI, Luchsinger PC et al. Pleural Effusions: The Diagnostic Separation of Transudates and Exudates. Ann Intern Med 1972;77:507-13

15. Liam CK, Lim KH, Wong CM. Differences in Pleural Fluid Characteristics, white Cell Count a Biochemistry of Tuberculous and Malignant Pleural Effusions. Med J Malaysia 2000;55:21-28
16. Melo FAF, AJB Santos ML et al. Diagnóstico da Tuberculose Pleural pela ADA, Isolada ou Combinada a Outras Variáveis, Inclusive em HIVPositivos. Folha Med 2000;119:19-21.

17. Vergnon JM, Guidollet J, Gateau O, Ripoll JP, Collet P, Louisot P et al. Lactic dehydrogenase isoenzyme electrophoretic patterns in the diagnosis of pleural effusion. Cancer 1984;54:507-11.

18. Gaga M, Papamichalis G, Bakakos P, Latsi P, Samara I, Koulouris NG, et al. Tuberculous Effusion: ADA Activity Correlates with CD4+ Cell Numbers in the Fluid the Pleura. Respiration 2005;72:160-65.

19. Pettersson T, Ojala $\mathrm{K}$ and Weber TH. Adenosine Deaminase in the Diagnosis of Pleural Effusions. Acta Med Scand 1984;215:299-304.

20. Ocanã I, Martinez-Vasquez JM, Ribera E, Segura RM and Pascual C. Adenosine Deaminase Activity in the Diagnosis of Lymphocytic Pleural Effusions of Tuberculous, Neoplastic and Lymphomatous Origin. Tubercle 1986;67:141-45.

21. Lee YC, Rogers JT, Rodriguez RM, Miller KD and Light RW. Adenosine Deaminase Levels in Nontuberculous Lymphocytic Pleural Effusions. Chest 2001;120:356-61.

22. Jimenez Castro D, Diaz Nuevo G, Perez Rodríguez E and Light RW. Diagnostic Value of Adenosine Deaminase in Nontuberculous Lymphocytic Pleural Effusions. Eur Respir J 2003;21:220-24.

23. Goto M, Noguchi Y, Koyama H, Hira K, Shimbo T and Fukui T. Diagnostic Value of Adenosine Deaminase in Tuberculous Pleural Effusion: A meta-analysis. Ann Clin Biochem 2003;40:374-81.

24. Chen ML, Yu WC, Lam CW, Au KM, Kong FY and Chan AY. Diagnostic Value of Pleural Fluid Adenosine Deaminase in Tuberculous Pleurisy. Clin Chim Acta 2004;341:101-107.

25. Smach MA, Garouch A, Charfeddine B, Ben Abdelaziz A, Dridi H, Krayem B, et al. Diagnostic Value of Serum and Pleural Fluid Adenosine Deaminase Activity in Tuberculous Pleurisy. Ann Biol Clin (Paris) 2006;64:265-70.

26. Valdés L, Alvarez D, San Jose E, Juanatey JR, Pose A, Valle JM et al Value of Adenosine Deaminase in the Diagnosis of Tuberculous Pleural Effusion in Young Patients in a Region of High Prevalence of Tuberculosis. Thorax 1995;50:600-603.

27. Diacon AH, Van de Wal BW, Wyser C ,Smedema JP, Bezuidenhout J and Bolliger CT et al. Diagnostic Tools in Tuberculous pleurisy: A Direct Comparative Study. Eur Respir 2003;22:589-91.

28. Antonangelo L. Desempenho Diagnóstico das Biopsias versus Citologia das Punções Aspirativas dos Derrames. In Aspectos Clínicos e Laboratoriais dos Derames Cavitários. $1^{\text {st }}$ ed., Rio de Janeiro, Revinter 2001. p 135-44 